\begin{tabular}{lllllllllll} 
O P E R A T I O N S R E S E A R C H A N D D E C I S I O N S \\
\hline
\end{tabular}

No. 3

DOI: $10.37190 /$ ord210305

\title{
SELECTED SOCIOECONOMIC FACTORS CO-OCCURRING WITH HIGH FERTILITY RATE IN THE OECD COUNTRIES
}

\author{
RADOSŁAW MURKOWSKI ${ }^{*}$ \\ Department of Business Activity and Economic Policy, Poznań University of Economics and Business, \\ al. Niepodległości 10, 61-875 Poznań, Poland
}

\begin{abstract}
This article presents the results of examining selected factors co-occurring with high fertility rates in developed countries. Selected OECD countries at a similar stage of demographic development have been subjected to analysis. Employing cluster analysis, the selected developed countries have also been identified according to the type of adopted family policy. It has been found that the developed countries which spend more on the family policy concerning GDP are generally characterised by higher fertility rates than those which spend less. In the light of those findings, the family-policy expenditures which allow women to reconcile professional work with raising children turned out to be particularly important. The fertility rate has also been found to correlate with labour market rates, with the level of women's professional activity in particular. Moreover, in the developed countries the relatively high fertility rate is accompanied by low rates of young people who do not work or attend school and are not in vocational training, as well as a high rate of extramarital births.
\end{abstract}

Keywords: family policy, total fertility rate, employment ratio of women, public social expenditure on families

\section{Introduction}

In the modern world, the family in developed and developing countries are subject to significant transformations related to a decrease in fertility and the number of births, a rise in the mean age of entering marriage, a decrease in the frequency of entering marriage, a significant increase of informal partnership, deciding to enter marriage at an older age, postponing first childbirth, a drop in family size, a rise in the percentage of one-person households and childless couples, rises in separation and divorce numbers, as well as the number of children born outside marriage. These changes are generally defined as a demographic transition, where the societies experiencing modernisation

*Email address: Radoslaw.Murkowski@ue.poznan.pl

Received 14 December 2020, accepted 2 September 2021 
move on from high fertility and mortality to a state where both fertility and mortality are low [1]. As a consequence, these changes lead to numerous demographic problems related to depopulation or the imbalance between people of productive age and the elderly. Therefore, in the light of these changes, it is important to establish what family policy is adopted by developed states, this contributes to maintaining the fertility rate at a moderately high level. It is also important to identify the factors which associate with high fertility rates in developed countries, which will facilitate a better understanding of the demographic processes taking place and possibly implement the relevant remedies. The study aims at verifying the hypothesis that the family policies adopted in some highly developed countries can effectively result in maintaining a relatively high fertility level. This concerns in particular those policies which boost families economically by reducing the financial cost of having children on the one hand, and making it easier for women to reconcile their professional activity with raising children on the other hand.

The countries which belong to the Organisation of Economic Cooperation and Development (OECD) which are at a similar stage of demographic development are selected for assessing the socioeconomic factors co-occurring with high fertility rates. The OECD is an organisation whose aim is to promote policy centred on achieving a higher and permanent economic growth, low unemployment rate and high living standards in member states, with maintaining financial stability at the same time. At present, there are 36 member states in the OECD, mainly economically developed ones, which, according to the theory of demographic shift, at the same time display a similar level of demographic, social and economic development. In the first empirical part of the article, the cluster analysis is applied to identify the states that are similar in terms of demography and the adopted family policy. Such an approach enables excluding from the analysis the OECD countries at a stage of demographic development other than phase 4, in the four-phase model of demographic transition. In the second experiential part, the occurrence of statistically significant interdependence between selected variables and the value of fertility rate in the successive year is scrutinised employing correlation and regression analysis. Such an approach enables the identification of macro-determinants co-occurring with high or low fertility rates in developed countries. The variables which co-occur with high or low fertility rates are divided into three groups: those directly related to the type of family policy, those related to the labour market, and other socioeconomic factors.

\section{Review of the literature}

The study does not aim at presenting an exhaustive overview of the literature on the macro-factors determining high or low fertility rates in developed countries; rather its 
purpose is to point at the rudimentary state of knowledge in this respect regarding the analysis carried out. An extensive literature overview in this area can be found in the work of Balbo, Billari and Mills [2]. There is extensive literature on the analysis of economic trends' influence on fertility, though findings seem to indicate that, for the developed countries, the connection between fertility and wealth measured by gross domestic product per capita is not unequivocal. Nevertheless, analyses point at decreasing fertility during the economic recession, though some researchers explain this is only a result of postponing (the first in particular) childbirth, which can be compensated for during a favourable economic situation [3]. In light of Easterline's theory of economic deprivation, the tendency to enter into marriage and have children is significantly reduced during historical periods of general economic uncertainty and rising unemployment.

Numerous findings have verified the influence of political means (e.g., labourmarket, fiscal, family, and housing policy) on fertility, though there is mixed evidence pointing at their effectiveness [5,6]. The analysis carried out by Kalwij [7] shows a positive influence on fertility levels in that the intensified expenditures on family policies help women reconcile family with employment, thus reducing the alternative cost of children. Researchers focus on various symptoms, lack of state support, describing the way such factors impede the reconciliation of work with family, by women, in particular, forcing them to choose between motherhood and a career, which leads to the postponement or resignation from children. Luci-Greulich and Thévenon [9] find that access to childcare for small children has more influence on the differences in fertility than the differences between the countries in terms of spending on direct family benefits for a child. The analysis carried out by Luci-Greulich and Thévenon is indicative of significant effects of cash transfers and the scope of childcare services for children under three on fertility trends, while the length of paid maternity leave was less significant in this regard. Kalwij [7] observes that childcare subsidies did not affect the time of birth, but they did have a positive effect on the second or third birth in the family and its total size. Hilgeman and Butts [10] find a significant effect of enrolling children in childcare centres on the total number of children born by women aged $18-45$ in the early 21 st century. Studies also indicate different importance of the adopted family policy instruments, depending on the character of the welfare state. For example, spending on cash benefits or childcare services for children under three has more importance for high levels of fertility rate in the Scandinavian countries than in the Anglo-Saxon ones [11]. It needs to be stressed at the same time that, although direct benefits for children have a smaller influence on fertility, in the light of many research findings, they enable achieving another family-policy aim to a larger extent, that is, reducing poverty and maintaining families' incomes at an unchanged level despite childbirth $[12,13]$. It should be taken into account at the same time that public policies in this area may differ both in terms of their scope (all-inclusive or directed towards families with low income) and the extent to which transfers 
are regressive or progressive relative to income, depending on family size. Being a key instrument in reducing poverty in families, housing allowances that grow according to family size can play a similar role $[13,14]$.

Studies also confirm the influence of unemployment and unstable situation in the labour market on postponing parenthood and they confirm a negative correlation: the higher the unemployment, the lower the fertility rate [15] whereas other researchers who scrutinise the relationship between the professional activity of women and fertility levels demonstrate that this interdependence changed in the 1980s from negative to positive. Sundström and Stafford [17] observe a strong positive relationship between total fertility rate and women's professional activity rate in 20 developed countries. Apps and Rees [18] demonstrate that the countries which supported families by better access to childcare alternatives to homecare and which made it easier for women to reconcile professional occupation with raising children had both better women supply in the labour market and higher fertility. In some developed countries, the policy of increasing fertility mainly aims at small children's mothers' staying at home and looking after children [19]. However, these two aims may be contradictory because women face a choice between having a child and employment, which can result in both smaller participation of women in the labour force and lower fertility than the case would be if women found both roles reconcilable.

Rindfuss and Brewster [20] claim that the following is an essential issue in developed countries: when women are capable of combining the role of a mother and that of an employee, both fertility and women's participation in the labour force will be relatively high. Generally, on a macro-level, the fertility rates are at present higher in countries of women's high employment rate, whereas a few decades ago the opposite situation prevailed $[21,22]$. Recent research stresses the importance of family policy which encourages higher fertility because it helps parents to reconcile family life and professional occupation (e.g., maternity leave entitlement, or access to childcare services for children under 3 in particular, and the possibility to work part-time) [10, 23, 24]. On the other hand, on a micro-level, the relationship between women's employment and having children seems to be less clear and the state should adopt the relevant family policy to help mothers reconcile both roles. The latest research studies indicate that having a stable employment contract is crucial for the decision to enlarge the family with a second or higher-order child, which is more strongly determined by financial constraints than the decision to have a first child [25]. Therefore employment instability -often gendered, with women more exposed to employment uncertainties than men - has become an intrinsic feature of the globalising world, and its effects on fertility will be a major research topic for years to come [26]. In some developed countries - mainly Scandinavian and post-communist - the institutional context reduces or generally eliminates the negative relationship between women's employment and childbirth [22]. 


\section{Grouping OECD states}

\subsection{OECD states and their level of demographic development}

Although the OECD states represent mainly countries with highly developed economies, not all of them are at the same stage of demographic development. For this reason, three groups of (cluster) countries with similar demographic indicators, loosely connected with demographic development, family policy or children's health (Fig. 1), are selected utilizing cluster analysis (Ward's method and Euclidean distance measurement were used). The analysis involves such variables as total fertility rate $\left(X_{1}\right)$, women's mean age at first childbirth $\left(X_{2}\right)$, extramarital births $\left(X_{3}\right)$, the number of married couples $\left(X_{4}\right)$ and the number of divorces $\left(X_{5}\right)$ per 1000 people, the mean duration of new-born babies' lives $\left(X_{6}\right)$, children's poverty rate $\left(X_{7}\right)$, infant mortality rate $\left(X_{8}\right)$, and neonates' mortality rate $\left(X_{9}\right)$ as well as the mean household size $\left(X_{10}\right)$ (Table 1).

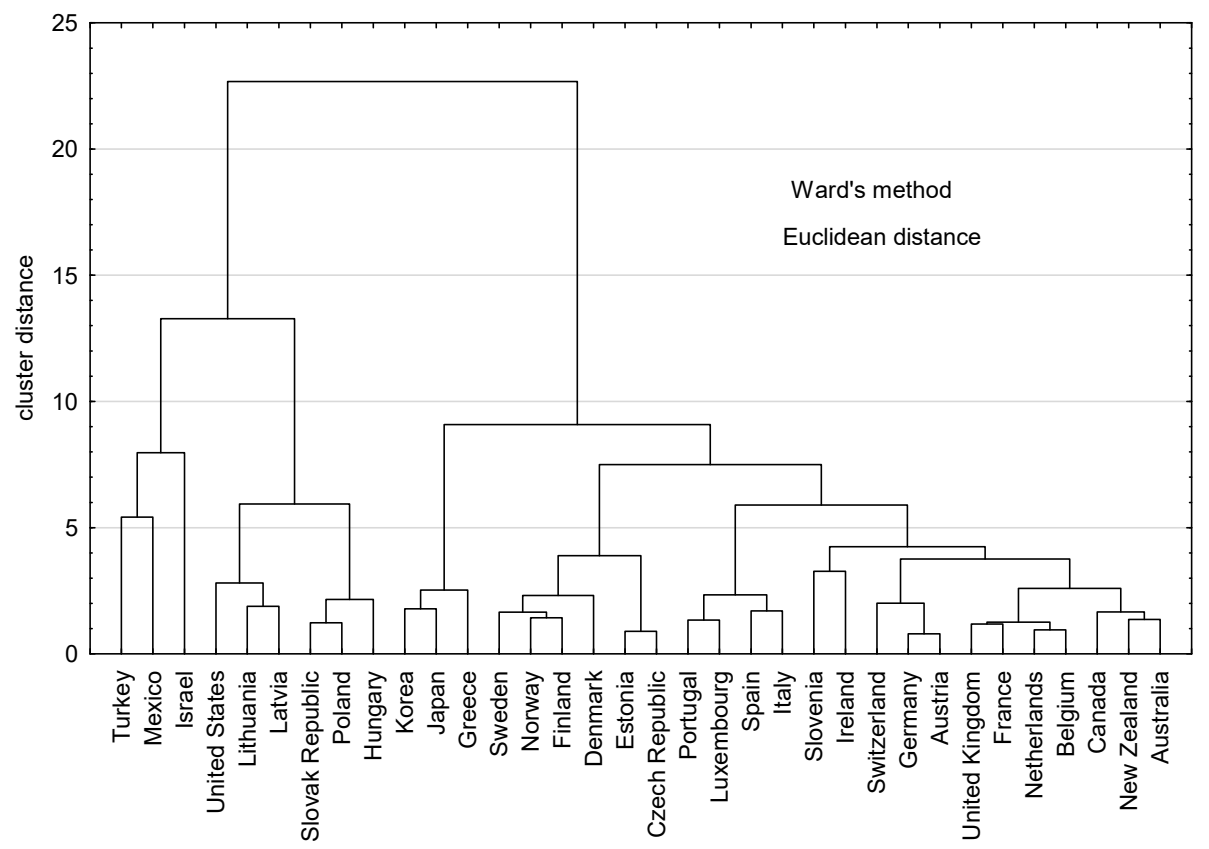

Fig. 1. Dendrogram of OECD countries similar in terms of selected demographic rates in the year 2015 (based on the OECD data)

Cluster No. 1 turns out to be the most numerous and it represents countries developed both economically and demographically (including France, Germany, Great Brit- 
ain, Ireland, Italy, Spain, Greece, Scandinavian countries, Austria, New Zealand, Canada, Korea, and Japan). This group exhibits the highest lifespan mean, the lowest ratio of children's poverty, as well as infant and neonate death rate. Nevertheless, these states are characterised by relatively different values of women's total fertility rates. On the one hand, one can find countries from Southern Europe in the group (Italy, Greece, Portugal, and Spain) and countries in the Far East (Japan and South Korea), where, on average, women give birth to 1.3-1.4 children during their childbearing period. On the other hand, in this cluster, one can also find such countries as New Zealand, Australia or countries of Western and Northern Europe (France, Great Britain, Ireland, Sweden), where women's fertility is maintained at a relatively high level amounting to $1.8-1.9$ children during the childbearing period. Regardless of this, the majority of the countries from this group are also characterised by the highest rate of extramarital births, and, at the same time, a small number of marriages registered per 1000 people.

Table 1. Groups of states similar in selected demographic indicators for the year 2015

(based on the OECD data)

\begin{tabular}{|c|c|c|c|c|c|c|c|c|c|c|c|}
\hline \multirow{2}{*}{$\begin{array}{c}\text { Cluster } \\
\text { No. }\end{array}$} & \multirow{2}{*}{ Specification } & \multicolumn{10}{|c|}{ Mean values in the group } \\
\hline & & $X_{1}$ & $X_{2}$ & $X_{3}$ & $X_{4}$ & $X_{5}$ & $X_{6}$ & $X_{7}$ & $X_{8}$ & $X_{9}$ & $X_{10}$ \\
\hline 1 & $\begin{array}{l}\text { Australia, Austria, Belgium, } \\
\text { Canada, the Czech Republic, } \\
\text { Denmark, Estonia, Finland, } \\
\text { France, Germany, Greece, } \\
\text { Iceland, Ireland, Italy, Japan, } \\
\text { Korea, Luxembourg, } \\
\text { the Netherlands, New Zealand, } \\
\text { Norway, Portugal, Slovenia, } \\
\text { Spain, Sweden, Switzerland, } \\
\text { the United Kingdom }\end{array}$ & 1.62 & 30.9 & 40.2 & 4.44 & 1.99 & 81.61 & 11.77 & 3.03 & 2.11 & 2.31 \\
\hline 2 & $\begin{array}{l}\text { Hungary, Latvia, Lithuania, } \\
\text { Poland, Slovakia, } \\
\text { the United States }\end{array}$ & 1.55 & 29.3 & 36.9 & 6.07 & 2.43 & 76.3 & 15.0 & 4.58 & 2.93 & 2.47 \\
\hline 3 & Israel, Mexico, Turkey, Chil & 2.33 & 28.6 & 36.7 & 5.53 & 1.12 & 78.7 & 22.9 & 8.18 & 5.43 & 3.58 \\
\hline
\end{tabular}

Cluster No. 2 includes countries from Eastern and Central Europe (Hungary, Latvia, Poland, Slovakia) and the USA. Against the other groups, these countries exhibit the lowest lifespan mean values and higher rates of infant and neonate mortality when compared to the first group. Moreover, the relatively low fertility rates, amounting to 1.55 children per woman in the childbearing period, are accompanied by the highest ratios of marriages and divorces in all the examined countries. At the same time, the countries which make up this group display an extramarital birth rate lower than in the first group and average age of women at childbirth. Due to migration, a significant drop in workforce supply is observed in the countries from Central and Eastern Europe, which accelerates the process of population ageing. For this reason, the countries which make up 
this group are still situated at a certain distance from the level of income per capita in the countries from the first group, which exposes them to the risk of growing old before becoming rich [27]. Nevertheless, it seems that alongside economic and social development in these countries, their demographic development will be more and more similar to that of the countries from the first group, which, in the light of the findings, has already taken place in the Czech Republic or Estonia.

The third cluster consists of only 4 OECD countries, that is Mexico, Turkey, Chile and Israel. This was the only group characterised by high fertility rates despite not big expenditures on pro-birth policy (this issue will be further discussed in the next section). These countries are also characterised by the lowest mean of women at first childbirth, the lowest divorce rate, and the highest registered marriages rates. Families in these countries are also significantly bigger than in the other groups - the average household size amounts to as many as 3.58 persons in the year 2015. At the same time, this group displays the highest children's poverty rate as well as these of infants and neonates. These countries are omitted from examining the factors co-occurring with high or low fertility levels because of the character of their demographic development - at present entirely different from the other OECD countries. In addition, countries such as Mexico, Turkey, and Chile are commonly regarded - taking into account, e.g., their Gross Domestic Product per capita or the social development rate (HDI) - as still developing, unlike the other OECD countries which are considered to be developed. Israel, regarded as a developed country, exhibits such peculiar demography that it should be treated as a distinct observation and omitted from the analysis of factors co-occurring with high or low fertility rates. It is the only country highly developed economically to show a fertility rate clearly exceeding the level of generation replacement - Israeli women gave birth to 3.1 children on average, compared to 1.7 in other developed countries. This is observed even though in many European countries with low birth rates there is much more generous state support of women and families with children. It seems that, in the case of Israel, the preference for having more children is largely boosted by a unique combination of pro-birth policy and a certain ideological narrative (the imperative of replacing the six million Jews murdered in the Holocaust, the collective fear of annihilation, the fear of Arab demographic dominance and the imminent war) [28].

\subsection{OECD countries according to family policies adopted}

Family policy is a part of a state's social policy and its most important purpose is to create proper conditions for the functioning of the family, which is the basic social institution. It can be assumed that family policy encompasses governments' policies and programmes directly or indirectly dedicated to families, affecting their functioning [29]. Amongst the numerous goals of family policy, one should enumerate, e.g., raising the birth rate, reducing family poverty, direct compensation of child-raising costs, boosting 
employment, actions supporting gender equality or supporting early development of children [30]. Politicians in the particular countries put stronger or weaker emphasis on the family policy which, in consequence, leads to a variation in combinations of selected family policy instruments, such as financial support, material support, tax breaks or financing services that facilitate reconciling professional occupation with raising children. Variations in the scope of the variability of these family policy instruments result from the dominating attitudes to families in each society, the governments' roles in this area or present-day family patterns $[31,32]$. In most present-day developed countries one of the most basic aims of family policy is to increase women's fertility rate up to the level of generation replaceability. The economic theory of fertility lies at the foundations of pro-birth policies applied by these countries. In the light of this theory, child demand depends on individual preferences and child-raising costs, including direct costs and alternative costs. Therefore, the policies which can help lower these costs will increase child demand among people.

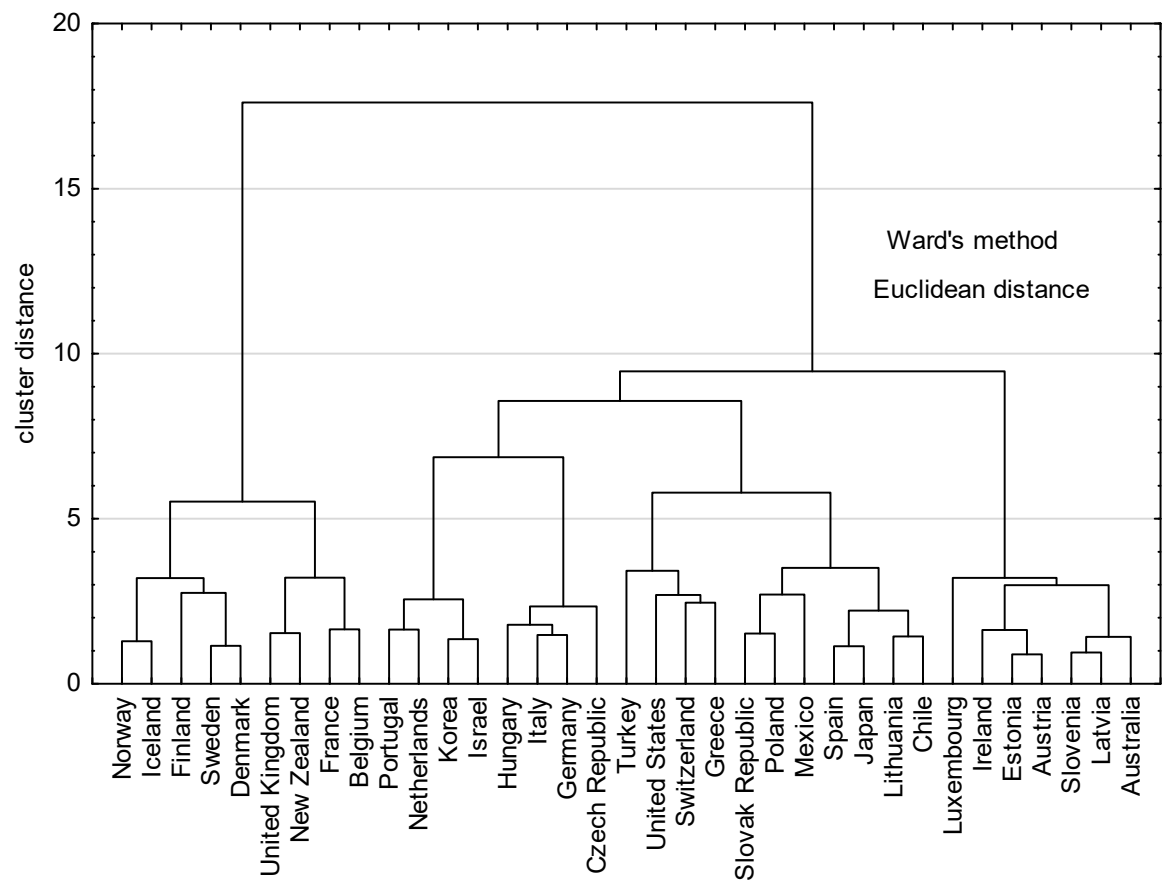

Fig. 2. Dendrogram of OECD countries similar in family policy type for the year 2015 (based on the OECD data)

A family-policy type manifests itself in the form of the instruments applied by different countries and reflected in the level of expenditures on particular tasks. Amongst the instruments applied by states, dedicated solely to families and children, one can 
enumerate, e.g., direct cash transfers for families with children (child benefit, additional payments during maternity leave, and financial support for single-parent families), public financial support of services for families with children (direct financing or subsiding of childcare centres and early-education centres, public support for children by granting funds to parents or public expenditures on family services, e.g., domestic help services of needing families), financial family support provided by the tax system (tax exemption, tax breaks for children) and financing children's education. From a broader perspective, the state's expenditures in other areas of social policy, such as health care or housing, may also help families, but they are not intended solely for them.

Table 2. Groups of states similar in the type of adopted family policy for the year 2005 (based on the OECD data)

\begin{tabular}{|c|l|c|c|c|c|c|c|}
\hline \multirow{2}{*}{$\begin{array}{c}\text { Cluster } \\
\text { No. }\end{array}$} & \multicolumn{1}{|c|}{ Specification } & \multicolumn{5}{|c|}{ Mean values in the group } \\
\cline { 3 - 8 } 1 & \multicolumn{1}{|c|}{$X_{1}$} & $X_{2}$ & $X_{3}$ & $X_{4}$ & $X_{5}$ & $X_{6}$ \\
\hline 2 & $\begin{array}{l}\text { Belgium, Denmark, Finland, France, } \\
\text { Iceland, New Zealand, Norway, Sweden, } \\
\text { the United Kingdom }\end{array}$ & 1.51 & 1.67 & 0.14 & 4.05 & 49.93 & 94.54 \\
\hline 2 & $\begin{array}{l}\text { Australia, Austria, Estonia, Ireland, Latvia, } \\
\text { Luxembourg, Slovenia, Canada }\end{array}$ & 1.71 & 0.69 & 0.04 & 3.13 & 36.79 & 87.01 \\
\hline 3 & $\begin{array}{l}\text { Czech Republic, Germany, Hungary, Israel, } \\
\text { Italy, Korea, the Netherlands, Portugal }\end{array}$ & 1.03 & 0.84 & 0.51 & 3.07 & 37.46 & 92.36 \\
\hline 4 & $\begin{array}{l}\text { Chile, Greece, Japan, Lithuania, Mexico, } \\
\text { Poland, Slovakia, Spain, Switzerland, } \\
\text { Turkey, the United States }\end{array}$ & 0.71 & 0.58 & 0.19 & 3.06 & 19.70 & 72.84 \\
\hline
\end{tabular}

The key feature distinguishing the adopted family policies in different countries is the scope within which the policy directed towards families offers combining financial help, right to maternity leave, and child-care services. Through the adopted policy, countries can encourage single women or women in partnership with children at school age to participate or discourage them from participating in the labour market [24, 32], and the differences among OECD countries in this regard are significant. In the study, the OECD countries are divided into groups of states similar concerning the family policy adopted for the year 2015 (Fig. 2, Table 2) For the analysis, such variables as public spending on financial support for families as a percentage of GDP $\left(X_{1}\right)$, public expenditures on services for families as the percentage of GDP $\left(X_{2}\right)$, public expenditures on tax breaks for families as the percentage of GDP $\left(X_{3}\right)$, spending on education (primary, secondary and post-secondary schools) as the percentage of GDP $\left(X_{4}\right)$, the percentage of children aged $0-2$ in formal childcare $\left(X_{5}\right)$ and the percentage of children aged 3-5 attending kindergarten or primary school $\left(X_{6}\right)$ are selected. On the one hand, public spending on these family benefits exceeds $3.5 \%$ of GDP in France, Hungary, Sweden, and the United Kingdom; on the other hand, they are significantly lower in Greece, Korea, Mexico, Spain, Turkey, and the USA, where they are lower than $1.5 \%$ of GDP. At the same 
time, some OECD countries put more emphasis mainly on direct cash transfers for families, while other states spend proportionally more on services for families with children, which better enables women to reconcile professional activity with raising children. Due to the adopted public policies, bigger or smaller proportions of children under six are covered by formal childcare in different countries.

The OECD states have been divided into four groups; the first cluster includes countries whose total spending on family policy amounts to the highest value relative to their GDP. These are mainly countries from Western Europe, such as Belgium, France, Great Britain, or countries homogeneous in this regard, such as the Scandinavian countries (Denmark, Sweden, Norway, Finland, Iceland) and New Zealand. The Scandinavian countries ensure all-embracing support for working parents with very young children (under three) by combining generous maternity leaves with commonly accessible childcare services [34]. English-speaking countries (Great Britain, New Zealand) ensure significantly smaller temporal and material support for working parents with very young children; they direct generous support mainly towards families with low incomes and children at kindergarten age [35]. From among the countries in continental Europe, France (to a smaller degree also Belgium) stands out, with relatively high public spending on families with children and stronger support for working women who have families. Generally, this group can be characterised by clearly the highest expenditures on family services relative to GDP (around $1.7 \%$ of GDP), which is mainly related to providing public care for small children. Such a policy has led to the highest rates of providing institutional care for children at nursery-school age (every second child) and kindergarten age (approximately $95 \%$ of children). Moreover, these countries spend relatively more on educating children and the youth - on average as much as $4 \%$ of GDP. At the same time, equally much is being spent in these countries on cash transfers for families, such as direct financial benefits for children and, to a lesser extent, tax breaks. The countries which make up this cluster are highly developed and are characterised by high fertility rates - on average 1.8 children per woman in the childbearing period.

The other countries of Western and Eastern Europe constitute a more heterogeneous group occupying an intermediate position between English-speaking and Scandinavian countries. The family policy in these countries focuses more on direct financial benefits for children, while these states' support for services enabling one to reconcile professional work with raising children under three is more limited. In turn, the countries of Northern Europe are characterised by limited support for working families and low public spending on family financial benefits and childcare services. Cluster No. 2 embraces quite different European countries such as Austria, Ireland, Estonia, Luxembourg and Slovenia as well as Canada and Australia. Within family policies, money is spent in these countries mainly on public cash transfers for families, usually in the form of direct benefits - the highest in all the examined groups; institutional childcare is financed there to a lesser extent. As a result of such a policy, institutional childcare covers around $37 \%$ of children under 3 and as many as $92 \%$ of kindergarten-aged children. In turn, cluster 
No. 3 is also quite varied and it mainly encompasses countries of Central, Western and Southern Europe, such as the Czech Republic, Germany, Hungary, the Netherlands, Portugal and Italy as well as such countries as Israel and Korea. The countries which make up this group spend the most of all the groups on tax breaks for families. Moreover, the countries in this group spent (2015) around 1\% of their GDP on direct benefits for families and $0.84 \%$ of GDP on childcare services. As a result of such a policy, institutional care covers $37 \%$ of children under 3 and as many as $92 \%$ of kindergarten-aged children.

Cluster No. 4 includes countries of Central and Southern Europe (Poland, Slovakia, Lithuania, Switzerland, Spain, Greece) and countries such as Chile, Turkey, Mexico, Japan, and the USA. From among all the examined OECD countries, the countries from this group spend the least of all on family policy, which results in the lowest rates of including children at nursery-school age and kindergarten age in institutional care and lower fertility rates (except for countries such as Mexico, Turkey, Chile, which are at a different stage of demographic development). In these countries, on average less than $1.5 \%$ of GDP in total is spent on family policy, mainly on direct cash transfers for families and, to a lesser extent, childcare services. As a result of such a family policy, institutional care covers only approximately $20 \%$ of children under 3 and only $73 \%$ of children at kindergarten age.

\section{Selected socioeconomic factors and fertility rate}

\subsection{Introduction}

Several dozen different variables which could co-occur with high or low fertility rates in developed countries are selected for the study. Table 3 presents only those values of factors noted in 2015 for which there is a statistically significant value of Pearson's linear correlation coefficient with total fertility coefficient in OECD countries in the subsequent year, that is 2016 . The study addresses 32 OECD states, excluding Mexico, Chile, Turkey, and Israel. The variables co-occurring with high or low fertility rates are divided into three groups: those directly related to the adopted family policy, those related to the labour market, and other socioeconomic factors.

From among the factors which do not display any significant correlation with fertility levels in OECD countries (a significance level limit of 0.05 is accepted), one may point at variables such as the length of paid maternity and parental leave available to mothers in weeks, gross domestic product per capita, infant and neonatal mortality rate, mean age of women at childbirth, crude marriage rates, divorces per 1000 people, life expectancy at birth, distribution (\%) of single parents working full-time with at least one child aged $0-14$, the gender gap in median earnings of full-time employees. It needs 
to be clearly emphasised that no connection between fertility rate and the wealth of the examined developed countries measured by, e.g., the level of GDP per capita is found.

Table 3. Pearson's linear correlation coefficients between total fertility rate for the year 2016 and selected variables for OECD countries for the year 2015 (based on the OECD data)

\begin{tabular}{|l|c|c|c|}
\hline \multicolumn{1}{|c|}{ Specification } & $\begin{array}{c}\text { Statis- } \\
\text { tics }\end{array}$ & $\begin{array}{c}\text { Degrees } \\
\text { of freedom } \\
d f\end{array}$ & $\begin{array}{c}\text { Significance } \\
p\end{array}$ \\
\hline \multicolumn{2}{|c|}{} & \multicolumn{2}{|c|}{} \\
\hline Public social expenditure for families as a per cent of GDP & 0.493 & 31 & 0.0040 \\
\hline $\begin{array}{l}\text { Expenditure on education (primary, secondary } \\
\text { and post-secondary non-tertiary) as per cent of GDP }\end{array}$ & 0.427 & 31 & 0.0146 \\
\hline $\begin{array}{l}\text { Public social expenditure on cash benefits } \\
\text { for families as a per cent of GDP }\end{array}$ & 0.296 & 31 & 0.1000 \\
\hline $\begin{array}{l}\text { Public social expenditure on services } \\
\text { and in-kind benefits for families as a per cent of GDP }\end{array}$ & 0.475 & 31 & 0.0059 \\
\hline Labour market indicators & 0.551 & 31 & 0.0010 \\
\hline Employment ratio of women ages 15-64 & -0.550 & 31 & 0.0011 \\
\hline $\begin{array}{l}\text { Gender gap (male-less-female) in the employment } \\
\text { to the population rate }\end{array}$ & 0.567 & 23 & 0.0037 \\
\hline $\begin{array}{l}\text { Distribution (\%) of children (aged 0-14) } \\
\text { in all households where all adults working }\end{array}$ & -0.667 & 23 & 0.0003 \\
\hline $\begin{array}{l}\text { Distribution (\%) of children (aged 0-14) in all households where } \\
\text { at least one adult working, at least one adult not working }\end{array}$ & -0.416 & 30 & 0.0199 \\
\hline \multicolumn{2}{|c|}{ Other socioeconomic indicators } \\
\hline Child poverty rate & -0.420 & 31 & 0.0165 \\
\hline $\begin{array}{l}\text { Low birth weight infants as a proportion } \\
\text { of total live births }\end{array}$ & -0.389 & 31 & 0.0274 \\
\hline Share of births outside of marriage & 0.574 & 30 & 0.0007 \\
\hline $\begin{array}{l}\text { Proportion of 15-29 year-olds not in employment, } \\
\text { education or training (NEET) }\end{array}$ & & \\
\hline
\end{tabular}

\subsection{Family policy indicators}

It is found in the study that the developed countries which spend more on family policy relative to their GDP are characterised by clearly higher values of total fertility rate (see the correlation coefficient in Table 3 and Fig. 3). Only direct benefits solely for families and children, support for families in the tax system, and public spending on services for families with children such as childcare in a public nursery are regarded as states' spending on family policy. In the year 2015, OECD states dedicated on average $2.4 \%$ of their GDP to family benefits of this kind, but the particular countries varied largely in this respect. On the one hand, public spending on family benefits exceeds 
$3.5 \%$ of GDP in France, Hungary, Sweden, Denmark, and the United Kingdom. On the other hand, however, it amounts to below 1.5\% of GDP in Greece, Korea, Spain, or the USA. The diversity and different patterns of the states' family policies throughout the world result primarily from differences in the ideological bases and the historical development of social policies in these countries [5]. As a consequence, some countries spend more public funds on direct transfers for families, while others more on social services for families and facilitating the reconciliation of professional work with raising children. However, not all the strategies lead to promoting conditions necessary for starting or enlarging a family to the same extent. The OECD states differ in the scope of expenditures dedicated to primary and secondary education - countries such as Norway, New Zealand, United Kingdom, Belgium, and Iceland dedicated to this purpose more than 4\% of GDP in 2015, while in Lithuania or Ireland it was less than $2.5 \%$ of GDP. The study also confirms that the OECD countries which spend more on their citizens' education are characterised by higher average fertility rates (see correlation coefficient value in Table 3 and Fig. 3).
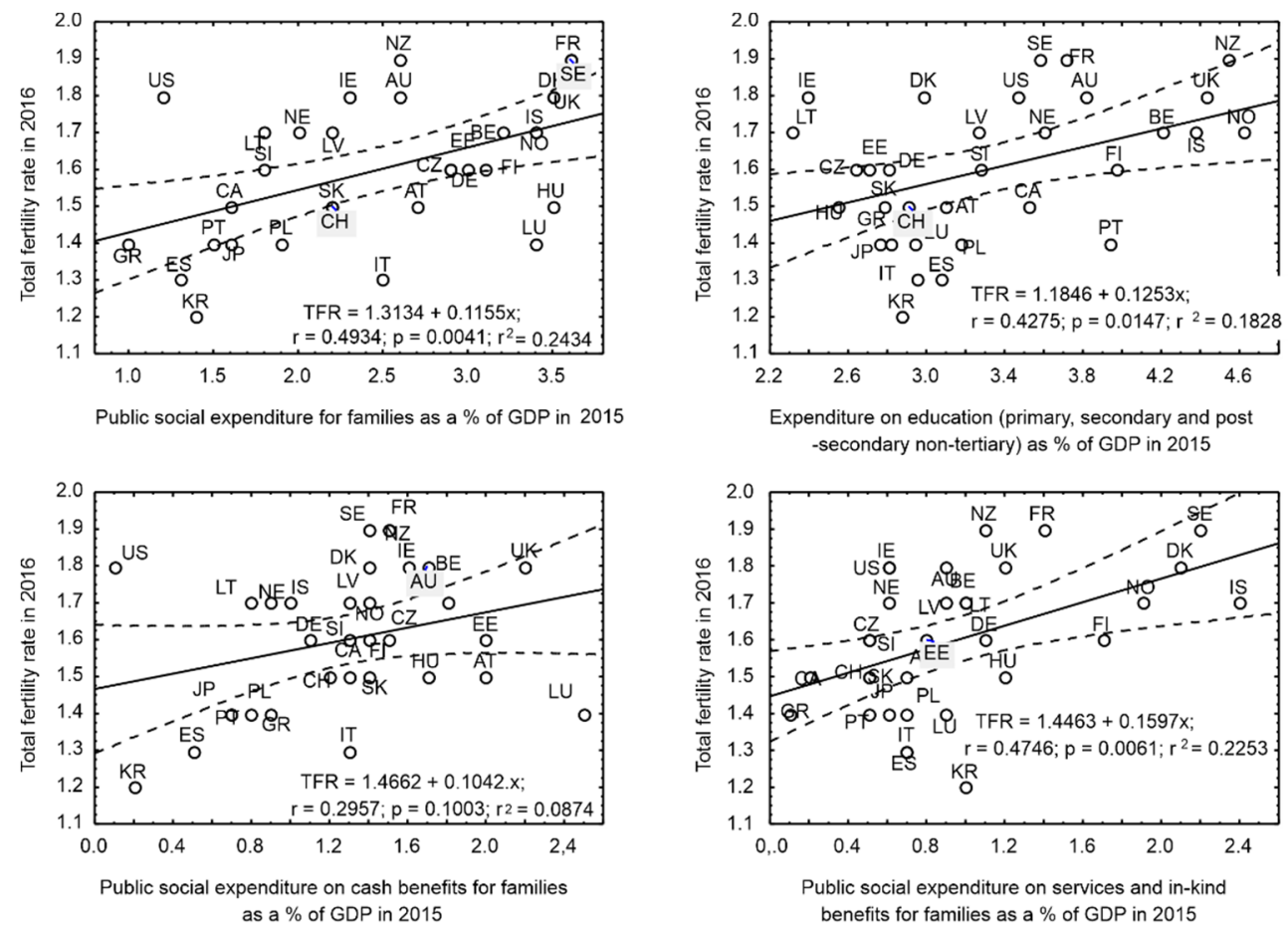

Fig. 3. Dependencies between states' expenditures on family policy relative to GDP and the fertility rate (based on OECD data)

Most, though not all, OECD countries spend more on cash benefits than on services or tax benefits. The exceptions include e.g. Denmark, Germany, Finland, Iceland, Lithuania, Korea, Mexico, the Netherlands, Norway, Spain, Sweden, or the USA, where 
service expenditures are at least slightly higher. Some countries also spend considerable amounts on tax breaks for families, e.g., in the Czech Republic, France, Germany, Hungary, Italy, and Switzerland public expenditures for tax breaks for families amount to $0.5 \%$ of GDP. It is found in the study that expenditures dedicated to direct money transfers are to a lesser extent correlated with high fertility rates (Pearson's linear correlation coefficient amounts to only 0.3 ) than expenditures dedicated to services for families enabling them to reconcile professional work with raising children (Pearson's linear correlation coefficient amounts to only 0.48 ). The study confirms a moderate and positive dependency between fertility rate and public spending on services for families with children in OECD countries, including direct financing or subsiding childcare centres and early education centres, which significantly enhances families' access to such kind of care.

\subsection{Labour market indicators}

Looking into the next group of factors related to the labour market, correlated with total fertility rate, one should take into account the fact that during the last decades there
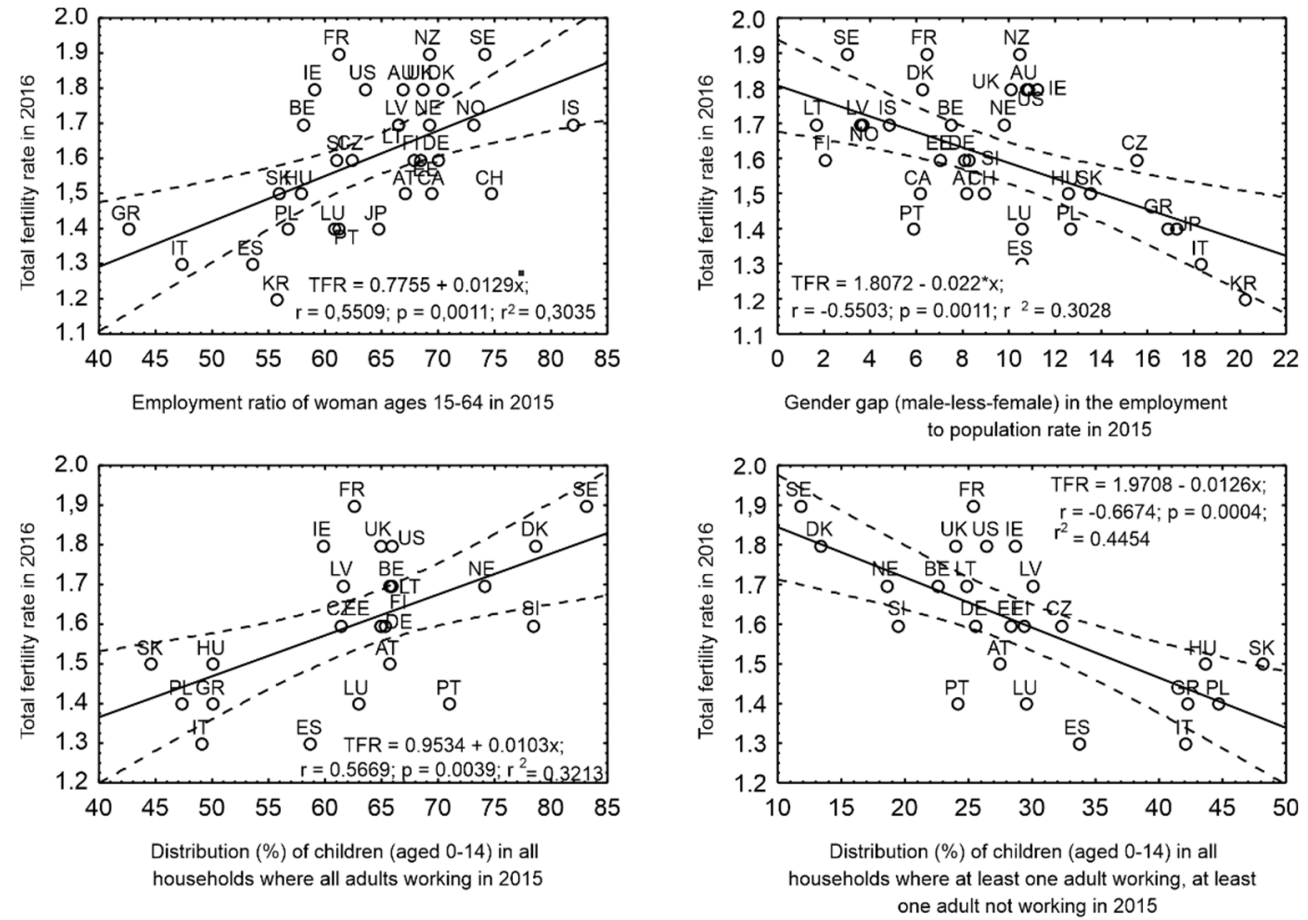

Fig. 4. Dependencies between selected indicators of the labour market and fertility rate (based on OECD data) 
has been a considerable increase in women's employment in developed countries. At the same time, not everywhere has there been satisfactory development of the states' institutional support aiming at helping working parents to meet the demands of parental duties $[30,36,37]$. The fact that different public policies adopted in developed countries have a different influence on women's employment and the possibility to reconcile a job with parental duties is of key importance in this regard. The study confirms a strong positive dependency between the level of women's professional activity and fertility rate in OECD countries (in this case, Pearson's linear correlation coefficient is statistically significant and amounts to 0.551 ). In turn, an inverse relationship occurs between fertility level and the gender gap in the employment-to-population rate (Pearson's linear correlation coefficient amounts to - 0.55). Similar results are indicated by quite a high negative dependency between the distribution (\%) of children (aged 0-14) in all households where at least one adult works and fertility rate (Pearson's linear correlation coefficient amounts to 0667) and quite a high positive dependency between the distribution (\%) of children (aged 0-14) in all households where all adults work and fertility rate (Pearson's linear correlation coefficient amounts to 0.567 ) (Fig. 4). For the examined countries, no correlation is found, e.g., between fertility rate and the length of paid maternity and parental leave available to mothers in weeks and the gender gap in median earnings of full-time employees.

\subsection{Other socioeconomic indicators}

Other factors of socioeconomic nature which could accompany high or low fertility rates are also taken into account in the study. What is interesting, the study does not find any correlation between wealth measured as GDP value per capita and the fertility rate. Whereas there is a moderate negative dependency between the percentage of youth aged 15-29 who do not study, do not work, and at the same time are not prepared for a profession (NEET) and fertility rate in developed countries (Fig. 5 and Table 3). The high percentage of youth outside employment and in education in the particular regions is an indicator of poor economic perspectives, accumulation of unfavourable conditions in the form of long-term unemployment and lack of perspectives for the future, a decrease in human capital level, and an increase in poverty, which certainly does not contribute to high fertility. In the light of other studies' findings, it should be mentioned that the youth percentage NEET strongly correlates with fertility levels mainly in the countries of Southern Europe; e.g., the rising youth percentage NEET among young adults has given rise to a drop in total fertility by almost 0.03 in Southern Europe alone [38].

A moderate dependency between the percentage of extramarital births and the fertility rate in developed countries is found in the study. As recently as a few decades ago, it was the legal marriage that was the dominant form of having and raising children in developed countries [39]. However, a decrease in the number of marriages occurred in 
the countries of Europe, North America, and the Pacific during the second demographic transformation, which brought about, among other things, an increase in extramarital births, thus contributing to extramarital fertility. Nowadays, however, childbirth outside formal marriage frequently occurs in the case of couples living in cohabitation which raise their children and manage a common household as married couples do. In the light of these findings, one may ask the question whether a more liberal approach to the scheme commonly referred to as "first wedding, then children" could have contributed in some countries to maintaining fertility rate at a higher level than in the case of more conservative societies in this regard. Let us consider the example of South Korea, where extramarital childbirth is rare and where the total fertility rate in the country (TFR, that is the mean number of children per woman) is extremely low and amounts to 1.2. One may wonder whether the fact that couples first need to start a household, which involves expenditures, creates problems in causing the country's fertility rate to increase [40].
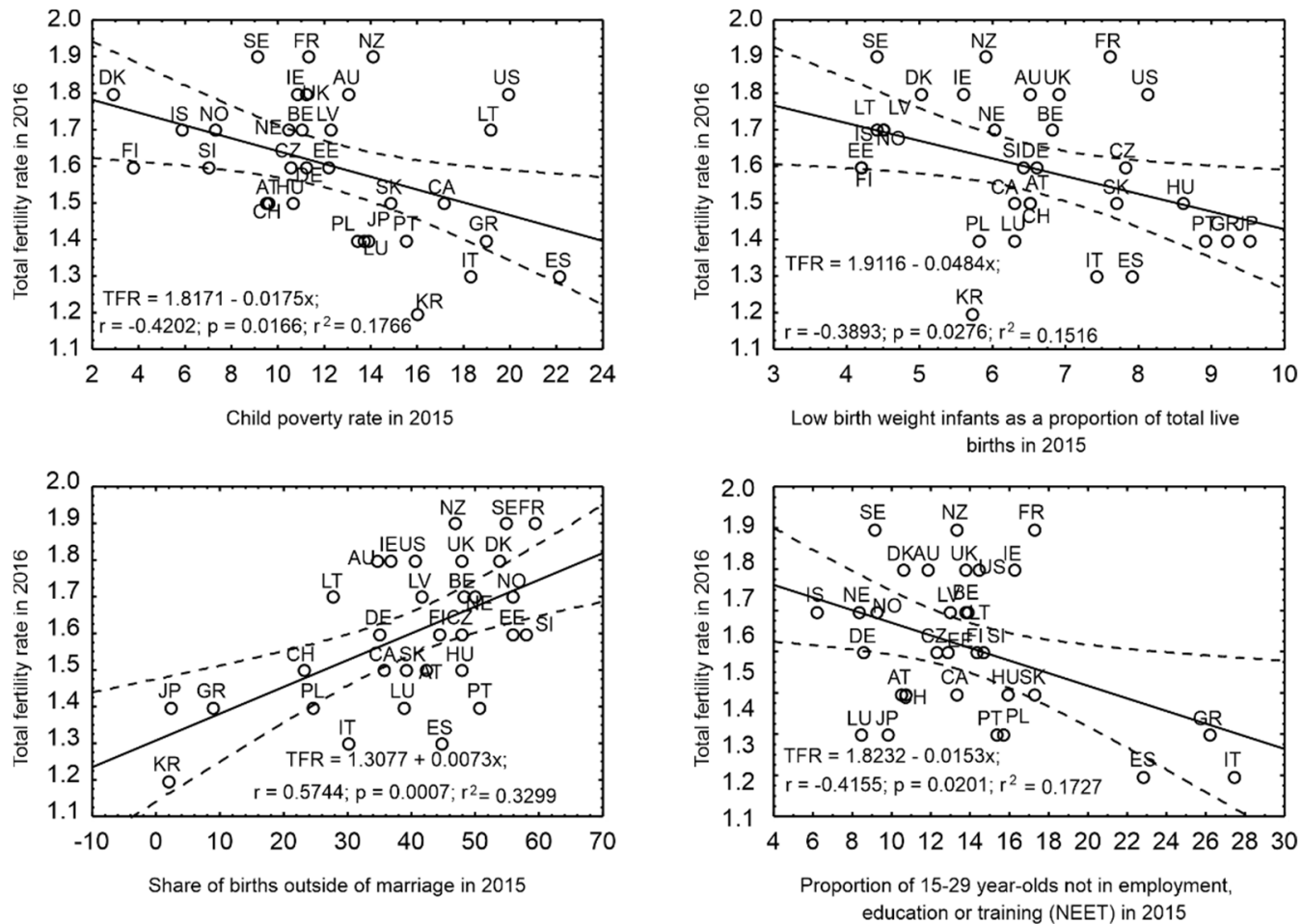

Fig. 5. The dependencies between selected socioeconomic indicators and fertility rates (based on OECD data)

A statistically significant moderate negative dependency between children's poverty indicator, and even the proportion of neonates' birth weight to all live births, and the fertility rate is identified in the study. These results can be looked at more broadly 
by analysing the interconnectedness of poverty and fertility in developed countries. Generally, in societies with a lower socioeconomic development - or, to put it simply, in poor countries - the birth rate is high. This is due to, among other things, the fact that in very poor countries maintaining high fertility rate and poverty are caused by a lack of economic growth and poor access to family planning, the child being a certain kind of insurance for elderly people's future. Then, as the economy grows and education together with health care improve, the fertility rate drops. In the light of Kuznets' demographic curve theory, inequalities of fertility increase at the early stages of demographic transformations, when groups of higher status reduce their fertility faster than poor people. Then they disappear at the subsequent stages of the transformation when new reproductive behaviours become more prevalent in the population, which leads to a convergence of fertility indicators of the poor and the non-poor [41]. Whereas based on the values of the examined correlation coefficients, it may be proposed that in the most developed countries the opposite situation may arise and it is the fertility of wealthy people that may be higher than that of the poorer ones.

\section{Discussion and conclusions}

Numerous demographic studies have equivocally confirmed the influence of family policy on fertility. This, however, is in evident contradiction of the high variability of fertility levels in the developed countries, which are moderately correlated with public spending on family policy. The study finds that the developed countries which spend more on family policy relative to their GDP are characterised by clearly higher values of total fertility rate. However, not all the strategies of the family policies lead to promoting conditions necessary for starting or enlarging a family to the same extent. In the light of the results of the study, not every kind of family policy correlates with high fertility to the same extent. It is found that family policy based only on direct benefits for children or tax relief whose purpose is to reduce direct financial burden connected with their raising does not display a high correlation with fertility. Welfare policies offer people some financial security and thus support them in realising their fertility desires even in adverse economic conditions [25]. However, financial factors are important in the decision about a higher-order birth, whereas the decision to have the first child is strongly determined by emotional reasons, such as the need to love and care for a child or the desire to bring spouses closer and experience fun around the house [42]. Higher correlations with fertility levels are observed for a strong family policy which boosts the position of women by enabling them to reconcile raising children with work by reducing alternative costs of children. Additionally, demographic policy should also take into account the existence of clearly positive interdependence between women's participation in the labour force and high fertility in developed countries. As a consequence, 
further strengthening the position of women should contribute to fertility, which is indicated by the clear interdependence between high fertility and the percentage of families in which both parents work.

In a nutshell, then, in the majority of the developed countries, the higher fertility rates are accompanied by high employment rates among women. This is conditioned by the existence of the whole institutional context enabling women to reconcile professional work with raising children, mainly in the form of access to formal childcare services for children under 3 and working parents [43]. Furthermore, different family policy instruments interact with each other and thus can improve or lower the general efficacy of the applied solutions, raising or lowering general fertility levels. The findings of the study demonstrate that the association between high fertility and women's professional activity is stronger when there are other measures supporting working mothers (e.g., employment protection, duration of paid maternity leave, direct child benefits regardless of the family's income). Together, these factors increase the stabilisation of family functioning, reducing uncertainty, which may even lead to the perpetual postponement of family formation and thus to smaller family size or even no children at all. Whereas the instrument in the form of direct cash benefits matters more in pursuing goals of family policy other than merely an increase in women's total fertility that reduces the level of families' poverty and ensures income stability.

\section{References}

[1] KIRK D., Demographic transition theory, Pop. Studies, 1996, 50, (3), 361-387.

[2] Balbo N., Billari F.B., Mills M., Fertility in advanced Societies: A Review of Research, Eur. J. Pop., 2013, 29 (1), 1-38.

[3] NeELs K., Temporal variation in unemployment rates and their association with tempo and quantum of fertility: Some evidence for Belgium, France and the Netherlands, The Annual Meeting of the Population Association of America, Dallas 2010.

[4] EASTERLIN R.A., The conflict between aspirations and resources, Pop. Dev. Rev., 1976, 2 (3), 417-425.

[5] NeYER G., Family policies and low fertility in Western Europe, Max Planck Institute for Demographic Research (MPIDR Working Paper), Rostock 2003.

[6] Hoem J.M., The impact of public policies on European fertility, Ch. 8. Overview, Dem. Res. Spec. Coll., 2008, 7 (19), 249-260.

[7] KalWIJ A., The impact of family policy expenditure on fertility in Western Europe, Demography, 2010, 47 (2), 503-519.

[8] MAYER K.U., Whose lives? How history, societies, and institutions define and shape life courses, Res. Human Dev., 2004, 1 (3), 161-187.

[9] LuCi-Greulich A., ThÉVEnon O., Does economic advancement "cause" a re-increase in Fertility? An empirical analysis for OECD countries (1960-2007), Eur. J. Pop., 2014, 30 (2), 187-221.

[10] Hilgeman C., Butts C., Women's employment and fertility: A welfare regime paradox, Soc. Sci. Res., 2009, 38, 103-117.

[11] Andersson G., Rønsen M., Knudsen L.B., LappegÅrd T., Neyer G., Skrede K., Teschner K., ViKat A., Cohort fertility patterns in the Nordic countries, Dem. Res., 2009, 20 (4), 313-352. 
[12] Maître B., Nolan B., Whelan C.T., Welfare regimes and household income packaging in the European Union, J. Eur. Soc. Pol., 2005, 15 (2), 157-171.

[13] Ritakallio V.-M., Bradshaw J., Family poverty in the European Union, [In:] J. Bradshaw, A. Hatland (Eds.), Social Policy, Family Change and Employment in Comparative Perspective, Edward Elgar, Cheltenham 2006.

[14] Fagnani J., Math M., Family packages in 11 European countries: Multiple approaches, [In:] A. Leira, C. Saraceno (Eds.), Childhood: Changing Contexts, Emerald Group Publishing Limited, Bingley 2008, 55-78.

[15] ORSAL D.D.K., GolDSTEIN J.R., The increasing importance of economic conditions for fertility, MPIDR Working Paper WP 2010-014, Max Planck Institute for Demographic Research, Rostock 2010.

[16] Benjamin K., Men, women, and low fertility. Analysis across time and country, unpublished Working Paper, University of North Carolina, 2001.

[17] SundSTRÖm M., STAFFord F., Female Labor Force Participation, Fertility and Public Policy, Stockholm Research Reports in Demography, Stockholm 1991, 63.

[18] Apps P.F., ReEs R., Fertility, Female Labor Supply and Public Policy, IZA Discussion Paper No. 409, 2001.

[19] Matysiak A., Vignoli D., Fertility and women's employment. A meta-analysis, Eur. J. Popul., 2008, 24 (4), 363-384.

[20] Rindfuss R.R., Brewster K.L., Childrearing and Fertility, Pop. Dev. Rev., 1996, 22, 258-289.

[21] Billari F.C., Kohler H.P., Patterns of low and lowest-low fertility in Europe, Pop. Studies, 2004, 58 (2), 161-176.

[22] Engelhardt H., Kögel T., Prskawetz A., On the changing correlation between fertility and female employment over space and time, Eur. J. Popul., 2004, 20, 35-62.

[23] Hobson B., OlÁH L.S., Birthstrikes? Agency and capabilities in the reconciliation of employment and family, J. Mar. Fam. Rev., 2006, 39, 197-227.

[24] ThÉVEnon O., GaUthier A., Family policies in developed countries. A "fertility booster" with side effects, Comm., Work and Fam., 2011, 14 (2), 197-216.

[25] Alderotti G., Vignoli D., Baccini M., MAtysiak A., Employment instability and fertility in Europe: A meta-analysis, Demography, 2021, 58 (3), 871-900.

[26] Vignoli D., Guetto R., Bazzani G., Pirani E., Minello A., A reflection on economic uncertainty and fertility in Europe. The narrative framework, Genus, 2020, 76 (1).

[27] Ilyina A., Lee J., Petrova I., Scott A., European Department, Demographic Headwinds in Central and Eastern Europe, International Monetary Fund, Washington 2019, 19/12.

[28] KRAFT D., Israel booms with babies as developed world's birth rates plummet. Here's why, The Christian Science Monitor, Mass, Boston 2018.

[29] Zimmerman L.S., Policy, social policy, and family policy: Concepts, concerns, and analytic tools author(s), J. Marr. Fam., 1979, 41 (3), 487-495.

[30] ThÉvenon O., Family Policies in OECD countries: A comparative analysis, Pop. Dev. Rev., 2011, 37 (2), 57-87.

[31] NeYer G., Family policies and low fertility in Western Europe, J. Pop. Soc. Sec., 2003, 1, 46-93.

[32] Hantrais L., Family policy matters: Responding to family change in Europe, Policy Press, London 2004.

[33] OECD, Doing Better for Families, OECD Publishing, Paris 2011.

[34] BJöRKLUnd A., Does family policy affect fertility? Lessons from Sweden, J. Popul. Econ., 2006, 19, $3-24$.

[35] McDonald P., Moyle H., Why do English-speaking countries have relatively high fertility?, J. Popul. Res., 2010, 27 (4), 247-273. 
[36] Blau F., Kahn L., Female labour supply: Why is the US falling behind? IZA Discussion Paper, 2013, 7140.

[37] JaUmotte F., Female labour force participation: Past trends and main determinants in OECD countries, Economics Department Working Paper, OECD, Paris 2003, 376.

[38] Matysiak A., Vignoli D., SobotKa T., The great recession and fertility in Europe: A sub-national analysis, Vienna Institute of Demography Working Papers, 2018, 2.

[39] KAA V., Europe's second demographic transition, Popul. Bull., 1987, 42 (1), 1-59.

[40] Sмith R.D., Marital fertility patterns and nonmarital birth ratios: an integrated approach, Genus, 2019, 75 (9).

[41] Eloundou-Enyegue P., Giroux S., Tenikue M., African transitions and fertility inequality: A demographic Kuznets hypothesis, Popul. Dev. Rev., 2017, 43 (1), 59-83.

[42] Bulatao R.A., Values and disvalues of children in successive childbearing decisions, Demography, $1981,18,1-25$.

[43] CASTLES F.G., 2003, The world turned upside down: Below replacement fertility, changing preferences and family-friendly public policy in 21 OECD countries, J. Eur. Soc. Pol., 2003, 13 (3), 209-227. 